\title{
Tanztheater - taneční divadlo (nevšední) všednosti: od Kurta Joosse k Pině Bausch
}

\section{Tanztheater - an Uncommonly Common Dance Theatre: from Kurt Joosse to Pina Bausch}

Barbora Kašparová

\begin{abstract}
Abstrakt
Tanztheater je experimentální žánr na pomezí divadla a tance, který se začal ve větší míre rozvíjet v západním Německu na konci 60. let minulého století. Jedná se o jeden z projevů tanečního divadla $v$ období postmoderny, který je sice ve svém výrazu a metodě experimentální, ale jeho vývoj se odehrával na oficiálních scénách městských divadel. Cílem studie je představit kořeny žánru tanztheater, jeho dobový kontext, podobu a režijní a choreografické metody na př́kladu choreografky a režisérky Piny Bausch (1940-2009).
\end{abstract}

\section{Klíčová slova}

Tanztheater; Ausdruckstanz; Pina Bausch; Kurt Jooss; Die Sprache des Tanztheaters; Stück; Tanztheater Wuppertal

\begin{abstract}
Tanztheater is an experimental genre between theatre and dance that originated in West Germany at the end of the 1960. While its form and staging methods can be regarded highly experimental, this postmodern genre of dance theatre was founded and developed in the institutional frame of official municipal theatres. The aim of the study is to present the roots of tanztheater, the historical context of the period it was invented in, and its character and choreographic methods on the example of its founder, choreographer and director Pina Bausch (1940-2009).
\end{abstract}

\section{Keywords}

Tanztheater; Ausdruckstanz; Pina Bausch; Kurt Jooss; Die Sprache des Tanztheaters; Stück; Tanztheater Wuppertal 
Vzhledem k tomu, nakolik je německá taneční kultura specifická a vývojově odlišná od české, rozhodla jsem se ji v rámci této studie uchopit terminologií německé taneční vědy. Český tanečně-vědný terminologický aparát totiž není natolik etablovaný ani přesný, aby bylo možné jej využít či v něm hledat ekvivalenty pro zahraniční (a bohužel i české) taneční projevy od poloviny 20. století po současnost. Úvodem je tedy potřeba vysvětlit několik pojmů, s nimiž v textu záměrně operuji. Prvními jsou pojmenování německých tanečních žánrů Ausdruckstanz ${ }^{1}$ a Tanztheater ${ }^{2}$. Pro účely své studie volím zachování německých termínů, nebot se jedná o žánry jasně vymezené, mající svou určitou poetiku, představitele i historii. Navzdory tomu, že se veškerá německá substantiva píši s velkým počátečním písmenem, přiklonila jsem se $\mathrm{k}$ variantě s písmenem malým, a sice ausdruckstanz a tanztheater. Termíny tak do jisté míry přizpůsobuji české gramatice a stavím je na roveň jiným označením žánrů přejatých z cizí kultury jako např. sitespecific či happening. Označení Tanztheater s velkým „T“ pak odkazuje na instituci jako např́iklad Tanztheater Wuppertal, Tanztheater Bremen či Tanztheater Darmstadt.

Dále je potřeba již úvodem studie okomentovat pojem Stück, kterým, opět v podobě s malým písmenem, označuji jednotlivé choreografické práce Piny Bausch. Tímto způsobem se snažím zachovat kontext specifického přístupu k produkci a tvorbě, jež Pina Bausch a i jiní choreografové tanztheateru uplatňovali. ${ }^{3}$ Konkrétně Pina Bausch začala pojmenovávat s uvedením tanečního večera Fürchtet euch nicht $\left(\right.$ Nižádný strach $\left.{ }^{4}\right)$ roku 1976 každé své dílo jednoduše Stück. Důvodem, proč se v překladu do češtiny nepřikláním k českému ekvivalentu inscenace, je následující skutečnost. V německém jazyce existují dvě varianty tohoto slova s podobným významem (jak se etabloval v české strukturalistické tradici), a sice die Inszenierung a zmíněný das Stück, pojem představení by pak bylo možné př̀ložit jako die Vorstellung nebo die Aufführung. Důležité ovšem je, že Pina Bausch nevolí pro svá díla pojem Inszenierung, ale Stück, což lze chápat v souvislostech odklonu od divadelní tradice jako vědomé vyhranění se vůči konvencím spojeným s uváděním klasického baletu, z čehož lze cítit i jistou míru nadsázky. Das Stück je totiž hovorový výraz, který lze v kontextu tvorby Piny Bausch navíc vnímat jako odkaz na procesualitu a neurčitost, kterou se její díla i tvưrčí př́ístupy vyznačují. Zdá se mi proto, že překlad inscenace by odváděl od této kontextové skutečnosti, jež se s tvorbou Piny Bausch a jejich př́slušností k specifickému žánru neodmyslitelně pojí. Pro svou studii tedy zachovávám počeštěnou podobu pojmu stück opět ve formě s malým písmenem.

1 Taneční žánr období meziválečného německého expresionismu. Německý Ausdruckstanz ve skutečnosti odpovídá českému avantgardnímu výrazovému tanci. Dokonce by bylo i příhodné německý termín překládat tímto pojmem, nebot český výrazový tanec se formoval převážně pod vlivem německého Ausdruckstanz vyučovaným na škole v Hellerau u Drážd’an, kde se české avantgardní tanečnice vzdělávaly. Pro účely této studie však budu pro německý výrazový tanec používat pojem Ausdruckstanz, aby byla jasnější kontinuita tanečního vývoje v Německu.

2 Německý postmoderní taneční žánr spojující tanec a rysy činoherního/nonverbálního/fyzického divadla. Doslovně lze termín přeložit jako tanečni divadlo. Tento překlad však není vhodný, nebot pod pojmem taneční divadlo je v českém prostředí chápána veškerá taneční produkce bez ohledu na specifika jednotlivých tanečních žánrů a forem.

3 Podrobnosti viz kapitola „Stück jako titul či podtitul díla“.

4 Použit překlad Ludvíka Kundery. 
Kdybych zvolila termín inscenace, úplně by se vytratila jedna, třebaže subtilní, významová rovina činnosti a tvorby Piny Bausch v Tanztheateru Wuppertal.

Tato studie vznikla na základě poznatků z výzkumu k bakalářské diplomové práci Tanztheater - taneční divadlo všednosti a Pina Bausch. Hlavní zdroje pro následující závěry představuje zejména reflexe německých teoretiků tance a kritiků tanztheateru a pak také práce s archivními materiály (hlavně recenzemi, programy a plakáty) a audiovizuálními záznamy v divadle Tanztheater Wuppertal. Avšak tento text představuje jen první elévský krok k vytvoření plnohodnotné recepce Piny Bausch v českém divadelně- a tanečně-vědném prostředí. Ulpívá proto spíše na holém popisu režijně-choreografických metod Piny Bausch, než aby je i důsledně interpretoval v kontextu postmoderního tance. Je nutné, aby si tento nedostatek čtenář uvědomil, aby mohl obsah studie vůbec brát vážně. Vytvoření teorie a interpretace je úkol příští. Zatím se jen pokusím rozšířit povědomí o experimentálním žánru spojujícím taneční a výsostně divadelní estetiku, což může být do jisté míry inspirativní v přemýšlení o současných divadelních tvarech mísících velké množství různorodých prvků. Seznámení s principy žánru tanztheater může posloužit jako př́klad toho, jakým způsobem mohou spolu dvě zdánlivě nesouvisející formy (zde tance a divadla) komunikovat a tvořit jeden výrazový celek.

\section{Znovuobjevení tanztheateru}

V roce 1986 bylo celé 6. číslo tanečního magazínu Ballet-Journal / Das Tanzarchiv ${ }^{5}$ věnováno ve své době modernímu tanečně-divadelnímu žánru tanztheater. Své dílčí studie, komentáře a recenze na téma tanztheater zde uveřejnili renomovaní němečtí kritici a teoretici jako např. Norbert Servos či Jochen Schmidt. Tito autoři pozdějších rozsáhlých publikací pojednávajících o tanztheateru a jeho tvůrcích zde vůbec poprvé uceleně popisují a definují experimentální taneční formu tanztheateru. Místy tak činí stejně experimentálním způsobem, nebot právě tvůrčí přístup je jednou z cest, jak tanztheater pojmout a v plnosti jej uchopit. Konec 80. let 20. století znamená pro tanztheater období plné rozkvětu a konečného uznání jak veřejností, tak kritickou obcí ${ }^{6}$, přestože se první projevy tohoto žánru objevují již na konci 70. let. Norbert Servos odpovídá na otázku, co je tanztheater, tragikomickou jednoaktovou fraškou In der Fremde (V cizině) ${ }^{7}$. Prostřednictvím tohoto absurdního dialogu Kritika a Diváka ve foyer divadla o svém zážitku z představení nahlíží Servos tanztheater metaforickým způsobem.

5 Německý časopis o tanečním divadle Ballett-Journal/Das Tanzarchiv vznikl v roce 1981 sloučením časopisů Ballett-Journal a Das Tanzarchiv a vycházel až do roku 2002, kdy byl nahrazen periodikem Tanz-Journal. Časopis Das Tanzarchiv byl založen již v roce 1953 tanečníkem, pedagogem a tanečním kritikem Kurtem Petersem v roce 1953 .

6 Po převzetí baletu Wuppertaler Bühnen v roce 1973 se Pina Bausch potýkala prvních deset let jak s malou návštěvností publika, tak s nepochopením tanečníků ve vlastním souboru, což sama zmiňuje v několika rozhovorech.

7 Všechny německé názvy děl a citace z německých publikací jsou v překladu autorky, není-li uvedeno jinak. 


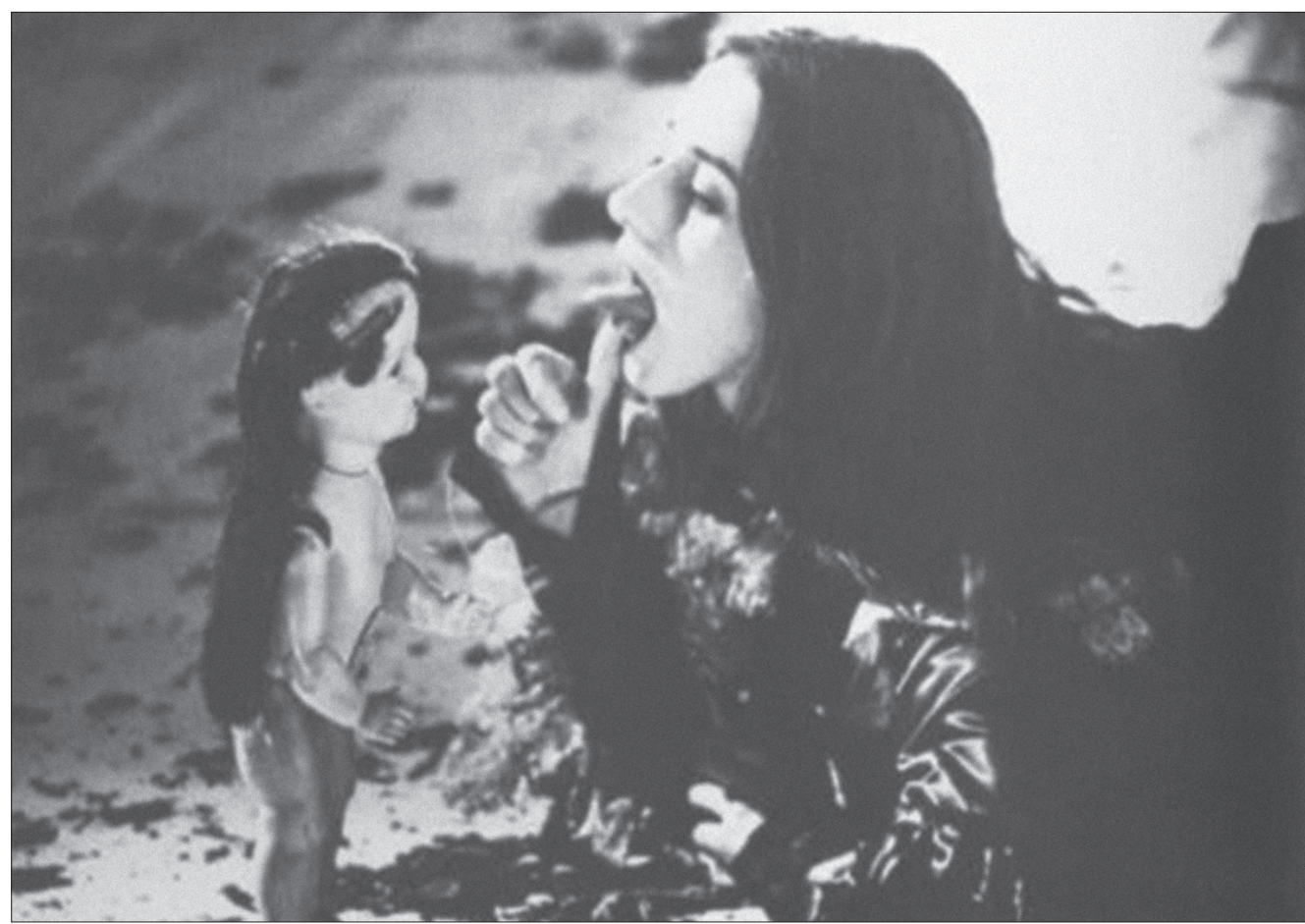

Obr. 1: Ze stücku Blaubart - beim Anhören einer Tonbandaufnahme von Béla Bartóks "Herzog Blaubarts Burg".

Divák (nesměle): Tak třeba nějaký příklad?

Kritik (znuděně): Když myslíte. (Vytáhne z tašky choreografa.) Co vidíte?

Divák: Choreografa.

Kritik (obrátí choreografovi obličej nazad, vykloubí mu paže, spoutá mu nohy): A ted'?

(SERVOS 1986: 10)

Servos vytváří skrze anekdotický obraz zmrzačeného choreografa přiléhavou paralelu k „neestetické“ a „vykloubené“ poetice tanztheateru. Choreografové tohoto divadelního žánru přestali pro velké operní scény tvořit iluzivní, poněkud naivní inscenace zajaté v technice „estetického“ neoklasického baletu a své choreografie začali komponovat $z$ více elementů: $\mathrm{z}$ tance (esteticky stylizovaného pohybu), mimetických gest, pantomimy, hereckého projevu, zpívaného a mluveného slova. Jejich ambicí bylo v choreografiích tematizovat soudobou společnost se všemi jejími skličujícími i radostnými tématy a za hlavní východisko si zvolili současného člověka, vykresleného v jeho nejupřímnějších emocích, vášních, smutcích a zvrácenostech. Jako př́ílad lze uvést drásavou scénu emočního i sexuálního zneužití naivní důvěřivé dívky, jejíž příběh tvoří pozadí a narativní propojení jednotlivých revuálních čísel stücku Fürchtet euch nicht (Nižádný strach). Zdánlivě vážná a upřímná známost končí znásilněním, jež je znázorněno obrazem dvojice dívky v průsvitné košilce a slizkého podvodníka v obleku a asi patnáctičlenného 


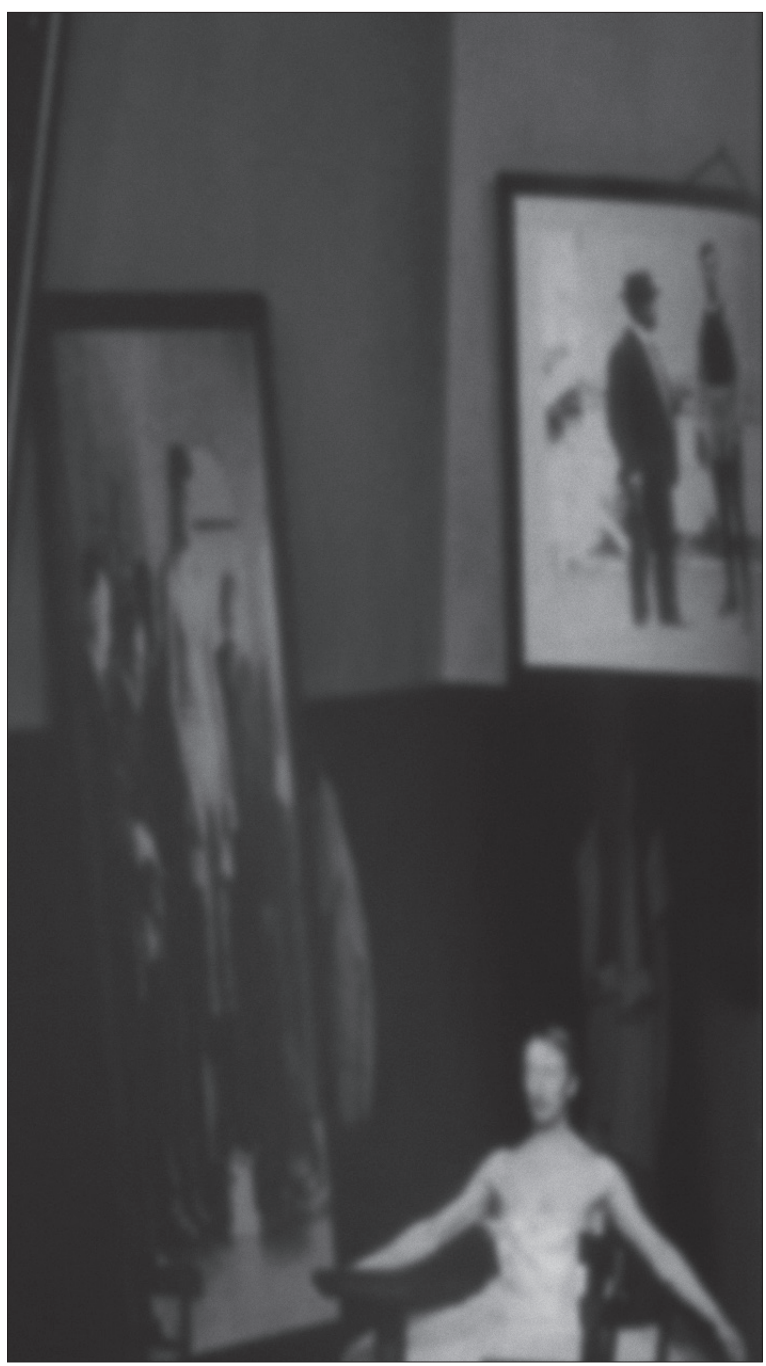

Obr. 2: Ze stücku Bandoneon - Ein Stück von Pina Bausch.

chóru tanečníků a tanečnic. Ti jsou bez rozdílu pohlaví výrazně nalíčeni, oblečeni do laciných různě barevných krátkých šatů a na hlavách mají levné paruky. Zatímco členové chóru zpívají píseň Alabama Song Kurta Weilla pohupujíce se do rytmu a opírajíce se vzájemně o sebe v nepravidelném chumlu uprostřed jeviště, muž se snaží lapit dívku prchající kolem chóru. Tato honička kočky s myší končí zápolením na péřovém polštáři za doprovodu hořkého Alabama Songu v podání chóru a malého orchestru umístěného v pozadí jeviště.

Tanztheater se na oficiálních scénách operních domů bývalého západního Německa začal ve větší míře objevovat v 60. a 70. letech 20. století a za nejvýraznější předsta- 
vitele jeho hlavní vlny jsou dnes považováni choreografové Johann Kresnik, Gustav Bohner, Reinhild Hoffmann, Susanne Linke a Pina Bausch. Německý tanztheater svou specifickou postmoderní taneční poetikou všednosti a ošklivosti nepř́ímo navazuje na avantgardní expresionistický taneční žánr ausdruckstanz, a proto je nutné hledat kořeny tanztheateru již v období mezi válkami. Jednu z vývojových linií od ausdruckstanz 20. a 30. let $\mathrm{k}$ tanztheateru 70. let až počátku 21. století představuje profesní vztah učitele a jeho žákyně, choreografů Kurta Joosse (1901-1979) a Piny Bausch (1940-2009), kteří ztělesňují propojení avantgardního ausdruckstanz a postmoderního tanztheateru.

\section{Die Sprache des Tanztheaters: první ozvuky žánru}

Kurt Jooss, zakladatel essenské experimentální umělecké školy Folkwangschule, bývá tradičně považován za prvního propagátora a tanečního učitele v duchu tanztheateru. Jooss se na bližším definování tohoto mezního žánru podílí krátkým textem „Die Sprache des Tanztheaters" (Jazyk tanztheateru), který napsal v exilu ve Velké Británii již v roce 1935. Článek kvůli Joossově pobytu v emigraci upadl v zapomnění a znovu se objevil až ve zmíněném čísle časopisu Ballett-Journal v roce 1986. Jooss zde popisuje smysl a potřebu nové taneční formy na pomezí realistického pantomimického hereckého výrazu a stylizovaného tance, která by mohla obsahově lépe odpovídat tématům současné společnosti a zároveň využít estetických možností techniky klasického tance.

Oba umělecké styly, ten „klasický“ i ten „nový“, jsou z hlediska své vlastní specifické estetiky úplné. Nebot jsou však ze své povahy zaměřené pouze jednostranně, samostatně se nedají dlouhodobě využít k vytvoření „všepojímajícího“ tanztheateru. Oba však obsahují ony vnější póly, mezi kterými se umění tance pohybuje. Proto musí být vytvořen třetí nadřazený kánon, který bude obsahovat elementy dvou předchozích stylů a přetaví je do harmonické jednoty. (JOOSS 1935: 17)

Někteří taneční teoretikové považují za první dílo tanztheateru Joossovu choreografii Der grüne Tisch (Zelený stůl) ${ }^{8}$ z roku 1932, která je otevřenou kritikou nastupujícího nacismu. V choreografii Jooss spojil klasické a moderní taneční styly, čímž naznačil kompromis mezi osobním výrazem a formálními závazky klasické techniky. Der grüne Tisch je ve své podstatě expresionistickým tanečním dramatem ve stylu německého žánru ausdruckstanz, ve kterém Jooss uskutečňuje své novátorské zásady učení o pohybu, které se tanztheateru blíží pouze některými svými rysy a ve skutečnosti ještě nejde o dílo v duchu poetiky tanztheateru, jak byla postupně ustanovována od konce 60. let. Der grüne Tisch má však s tanztheaterem společný rys společenské či politické angažovanosti. Jednou z důležitých součástí tanztheateru, jak jej definuje německá taneční teoretička Sabine Huschka, je stejně jako v Joossově choreografii společensko-politický kontext, který poskytuje půdu a témata pro tvůrce tanztheatru.

8 V Paříži byl za Zelený strul Jooss oceněn první cenou v choreografické soutěži Concours de Chorégraphie. 


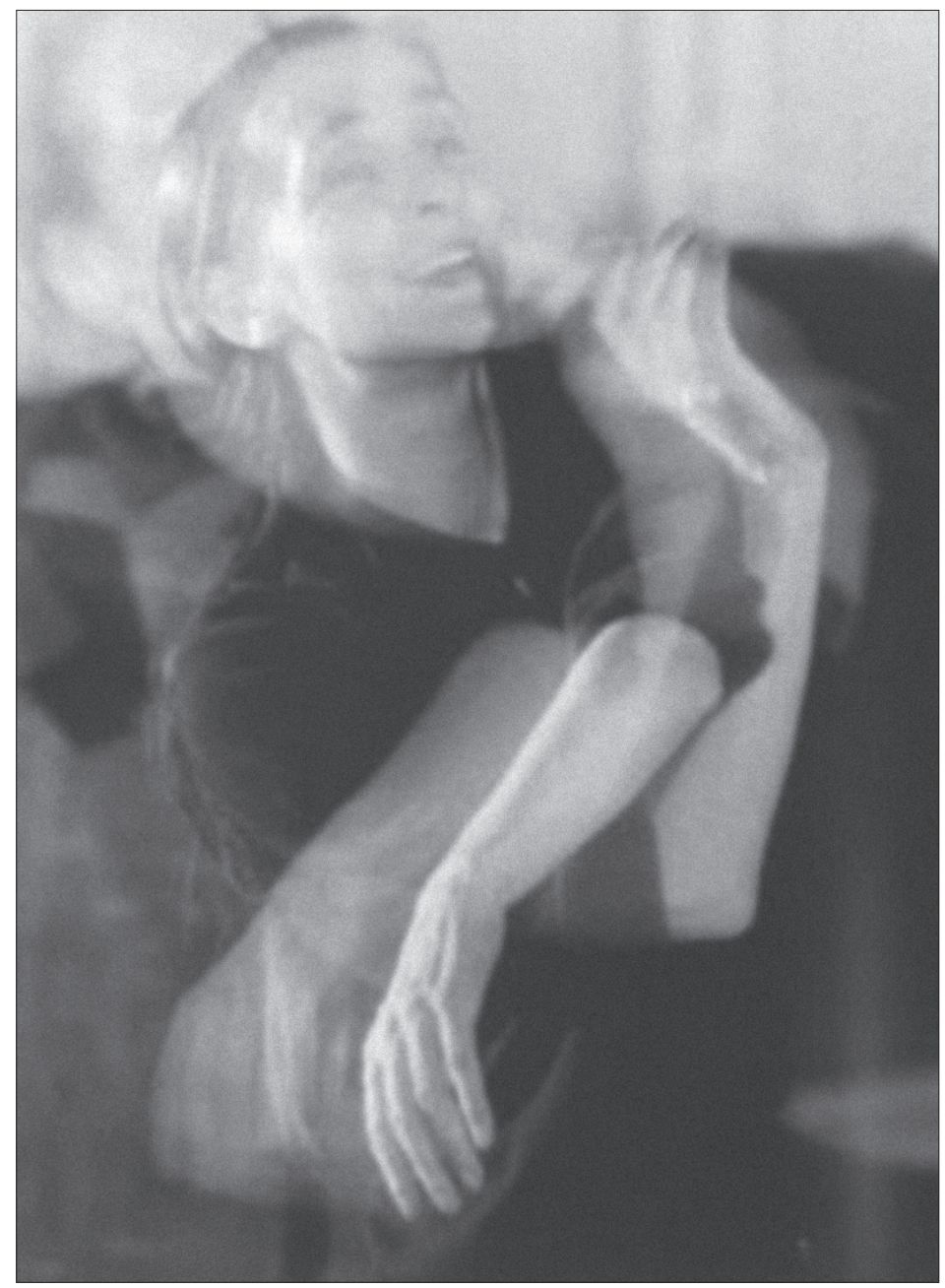

Obr. 3: Pina Bausch.

Komponovat tanec v duchu tanztheateru nespočívá ve vytvoření určité estetické koncepce pro choreografii, ale jeho kontext určuje - zboříme-li konvenční vymezení žánru - vypořádání se s historií média tance a historií těla jako se společensko-individuálním a estetickým konstruktem z obrazů, forem chování a z podnětů vyjadřování. Tím mění scénický žánr tance své estetické konstanty a stává se - především v 60. a 70. letech - vyostřeným společenskopolitickým statementem. (HUSCHKA 2002: 278)

Jednou ze zásad tanztheateru je chápání neodlučitelné jednoty těla a duše a hledání souvislosti mezi vnitřním výrazem a z něho vyrůstající pohybové kvality. Tomuto principu odpovídají i experimentální režijní metody a přístupy choreografů, o kterých bude řeč později. Přestože Kurt Jooss zastupuje ve své době taneční poetiku ausdruckstanz, je z textu „Die Sprache des Tanztheaters“ patrno, že si již před válkou kladl otázku, 
jak je možné s moderním tancem nadále pracovat. Kvưli nástupu nacistického režimu však mohl své myšlenky dovršit až po válce po návratu z exilu v roce 1949. Jeho tvưrčí prostor představovala půda znovuotevřené essenské střední umělecké školy Folkwangschule, která se po válce stala jedním z center experimentálního myšlení nejen o tanečním uměnî. Vystudovaly zde mimo jiné dvě významné choreografky tanztheateru Pina Bausch a Reinhild Hoffmann. Folkwangschule se po návratu Kurta Joosse z emigrace obecně zaměřovala na všechny druhy umění a hlavní ideou byla spolupráce a výměna zkušeností studentů rozdílných vyučovaných oborů. Studenti fotografie tak navštěvovali hodiny tance, kde fotografovali tanečníky, tanečníci se zase učili zpívat a hudebníci tančit. Druhé avantgardní taneční centrum představovalo po druhé světové válce berlínské Mary Wigman-Studio, kde vystudovala tanečnice a choreografka stejné generace jako Bausch Susanne Linke. Jak Kurt Jooss v Essenu, tak Mary Wigman v západním Berlíně tvoří svou převážně pedagogickou činností předěl mezi meziválečným ausdruckstanz a poválečným žánrem tanztheater. Obě školy se staly po druhé světové válce důležitými tanečními vzdělávacími institucemi, které se snažily ve zruinovaném Německu vzkřísit moderní tanec a podařilo se jim alespoň $\mathrm{v}$ určité míre navázat na tradici avantgardního ausdruckstanz tím, že poskytly vhodnou půdu pro kreativní myšlení o tanci, pohybu, osobnosti tanečníka a vztahu tanečního umění ke společnosti (SCHULZE-REUBER 2005: 29-35).

\section{Počátky tanztheateru}

V západním Německu se těsně po druhé světové válce věnovali choreografové oficiálních scén převážně „novému“ baletu francouzského, anglického a amerického stylu inspirovaní např́íklad tvorbou Maurice Béjarta ${ }^{10}$. Ve východním Německu byl vzorem nové baletní estetiky sovětský balet. Přes odlišnou inspiraci v baletním stylu v západním a východním Německu bylo jednotně rozhodnuto, že éra meziválečného ausdruckstanz je u konce a taneční platformu ovládl „nový“ neoklasický gymnastický balet. Jako symbolické dovršení této změny je možné vnímat sebevraždu expresionistické choreografky a tanečnice Dore Hoyer na přelomu let 1967 a 1968, která již neviděla šanci pro uplatnění své taneční formy. Poválečná společnost zřejmě neměla zájem o představení drásavého a expresivního tance v duchu avantgardního ausdruckstanz. Generaci 50. a 60. let, která se musela vyrovnat $\mathrm{s}$ důsledky prohry Německa $\mathrm{v}$ druhé světové válce a se svou nacistickou minulostí, se zdál ausdruckstanz př́liš těžký, temný a koneckonců ve svých výrazových prostředcích i př́liš realistický. Publikum si žádalo odlehčenější a estetizovanější styl, který se k realitě př́liš nevyjadřoval a spíše tvořil její antirealistický protipól. Choreografové jako Kurt Jooss, Mary Wigman, Gret Palluca, Dore Hoyer, Harald Kreutzberg a Valeska Gert se snažili vzkřísit meziválečný ausdruckstanz hlavně tím, že

9 Dnešní Folkwang-Universität der Künste byla založena roku 1927 tehdejším ředitelem essenské opery Rudolfem Schulz-Dornburgem, scénografem Heinem Heckrothem a choreografem Kurtem Joossem. Název Folkwang odkazuje na germánskou bohyni krásy a lásky Freyu, jejíž sál nesl jméno Folkwang.

10 Mezi ně patř́i např́íklad i choreografové Erich Walter Schäfer a Ivan Sertic působící ve Wuppertalu před Pinou Bausch. 
se věnovali pedagogické činnosti a jejich snaha vést své žáky k experimentálnímu myšlení o tanci poté vykrystalizovala koncem 60 . a začátkem 70 . let ve zrod tanztheateru.

$\mathrm{V}$ této době začínají v tanečním umění rezonovat nové impulsy vymezující se vůči neoklasickému baletu. Podobně jako na počátku dvacátého století osvobodili Isadora Duncan, Jacques Dalcroze a Rudolf von Laban tanečníkovo tělo od vyprázdněného vyjádření a konvencí převážně formálně a technicky směřovaného baletu, tak i v šedesátých letech se zase proti neoklasickému baletnímu žánru vytvořila taneční poetika, kterou reprezentují právě začínající tvůrci tanztheateru Johann Kresnik a Gerhard Bohner. Snaha vytvořit nové taneční prostředky, které by lépe reflektovaly současnou společenskou situaci, se poprvé projevila přibližně v polovině šedesátých let, kdy začal roku 1964 Gerhard Bohner tvořit v Berlíně. Druhou, již silnější tendencí vyhranit se vưči klasickému učení tance, byl v roce 1967 choreografický debut Johanna Kresnika O sela Pei, ve kterém zobrazuje komplikovaný vnitřní svět schizofrenií postiženého člověka, a jeho choreografie Paradies? (Ráj?) z roku 1968, kterou reagoval na studentské nepokoje tvrdě potlačené policií. Další z nenápadných, ale pevných nitek vedoucích k ukotvení kritikou ještě nereflektovaných tendencí a př́stupů tanztheateru představuje převzetí taneční skupiny při Folkwangschule Folkwang-Ballet Pinou Bausch roku 1968, který vedla až do roku 1973, kdy se stala uměleckou šéfkou baletního souboru ve Wuppertalu. Bohner, Kresnik a Bausch tak přivedli na konci 60 . a na začátku 70. let tanztheater na oficiální městské scény. ${ }^{11}$

Nutno však dodat, že linie neoklasického tance se záhy také proměnila a vytvořila plnohodnotný umělecký protipól angažovanému tanztheateru. Centrem neoklasického baletu se stal Stuttgarter Ballet, kam Erich Walter Schäfer v roce 1961 přizval ke spolupráci původem jihoafrického choreografa Johna Cranka. On a další choreografické osobnosti jako např́íklad John Neumeier, Jiří Kylián a William Forsythe představují v rámci svého žánru stejně progresivní př́stup $\mathrm{k}$ taneční tvorbě jako tvưrci tanztheateru.

\section{Podoba tanztheateru: tanec jako divadlo a jako život}

Poetika tanztheateru se nevyznačuje jednotnou technikou jako klasický balet či jiný formální styl tance. Stejně jako např́klad u modern dance či ausdruckstanz se podoba tanztheateru odvijí převážně od osobnosti jednotlivých choreografü, kteří rozvíjí za pomoci různých technik a samostatně vyvinutých přistupů svou osobitou taneční techniku a režijně-choreografické gesto. Přes značné odlišnosti v choreografích jednotlivých tvůrců je však možné sledovat společné tendence, které provází proud tanztheateru zejména od konce 60 . do počátku 80 . let.

Typickým rysem tanztheateru je inspirace žánry vaudeville, revue či slap stick a principy koláže. Choreografie se velmi často skládají z jednotlivých menších tanečních

11 Johann Kresnik se stal roku 1968 baletním ředitelem divadla v Brémách a začal zde propagovat svůj taneční styl. První oficiální scéna tanztheateru vznikla v Darmstadtu pod vedením Gerharda Bohnera, který původní baletní soubor po svém nástupu do ředitelské funkce v roce 1972 přejmenoval na Tanztheater Darmstadt. Vzápětí vznikly další Tanztheatery, a sice roku 1973 Tanztheater Wuppertal pod vedením Piny Bausch a Tanztheater Bremen pod vedením Gerharda Bohnera a Reinhild Hoffmann. 


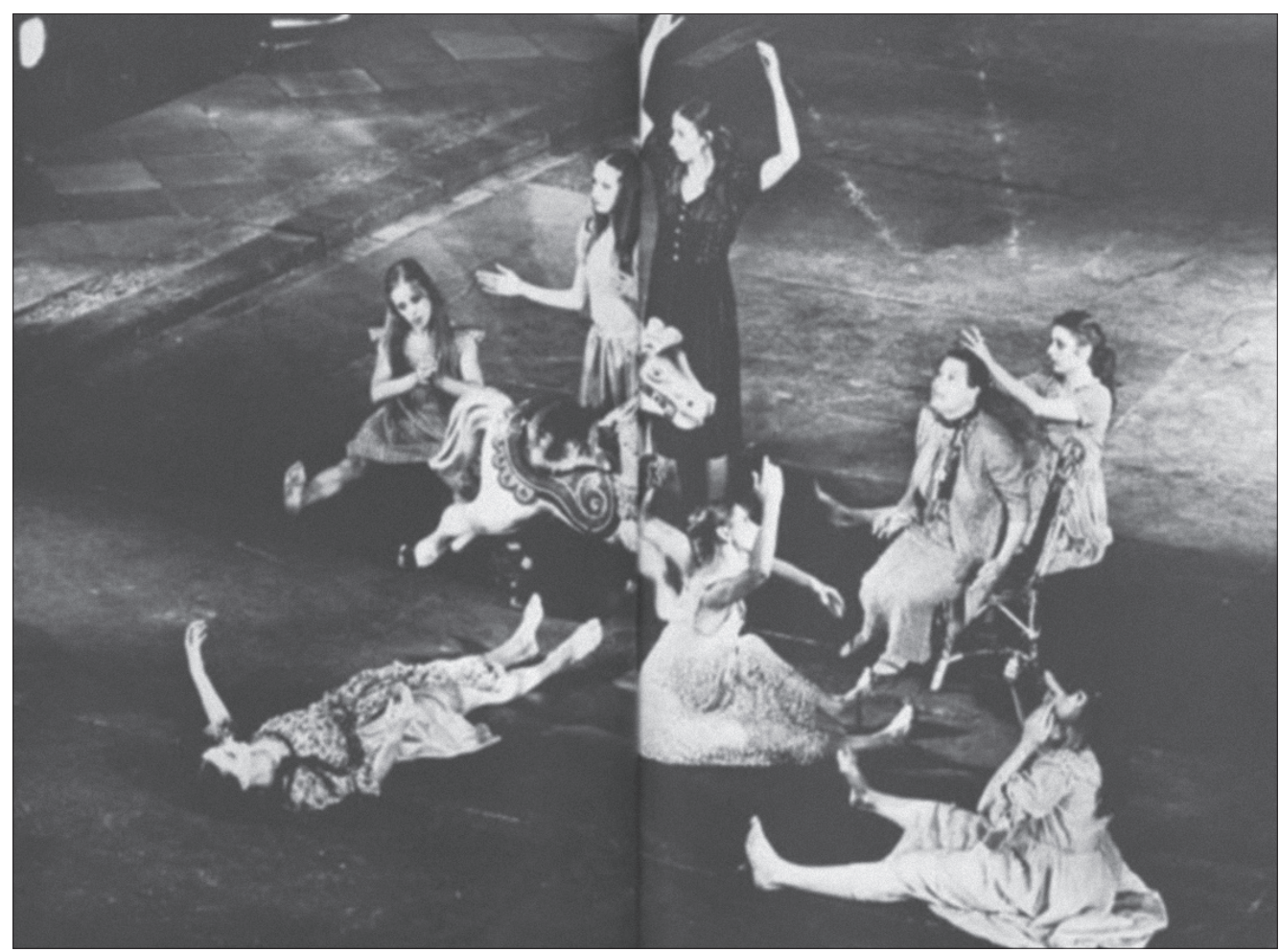

Obr. 4: Výstup zpěvačky (na židli) s tanečnicemi-panenkami ve stücku Fürchtet euch nicht.

výstupů, čímž je rozbita narace. Dramaturgický koncept čísel jdoucích postupně za sebou je posílen i výběrem hudby čerpajícím z folklórních písní, popových songů, balad, šansonů a tanečních skladeb, například valčíku, foxtrottu a rock'n'rollu. Choreografové se nezajímali o estetiku krásného bezchybně se hýbajícího těla. Tělo a pohyb tanečníka, mnohdy také vzdělaného klasickou baletní technikou, chápali jako prostředek k tvorbě dalších významů a přestali pojímat krásu tanečního pohybu jako konstantní hodnotu samu o sobě. Tvůrci tanztheateru vytvářeli osobitý pohybový jazyk vyjadřující lidská témata ze skutečného života. Příběhy tanztheateru vypráví o všedních lidech a jejich prožívání každodennosti. Centrálními náměty jsou emoce vyrůstající ze sociálního prostředí člověka jako bolest, smutek, osamělost, touha a melancholie, konflikty a komunikace mezi muži a ženami či radikální pojednání společenských a politických problémů.

\section{Tanztheater Piny Bausch}

Jako symbol či ikona pojmu tanztheater vynikl vedle všech ostatních významných skupin Tanztheater Wuppertal pod vedením tanečnice a choreografky Piny Bausch. Její příchod do Wuppertalu roku 1973 se sice pojil s nevolí jak konzervativního maloměštáckého pu- 


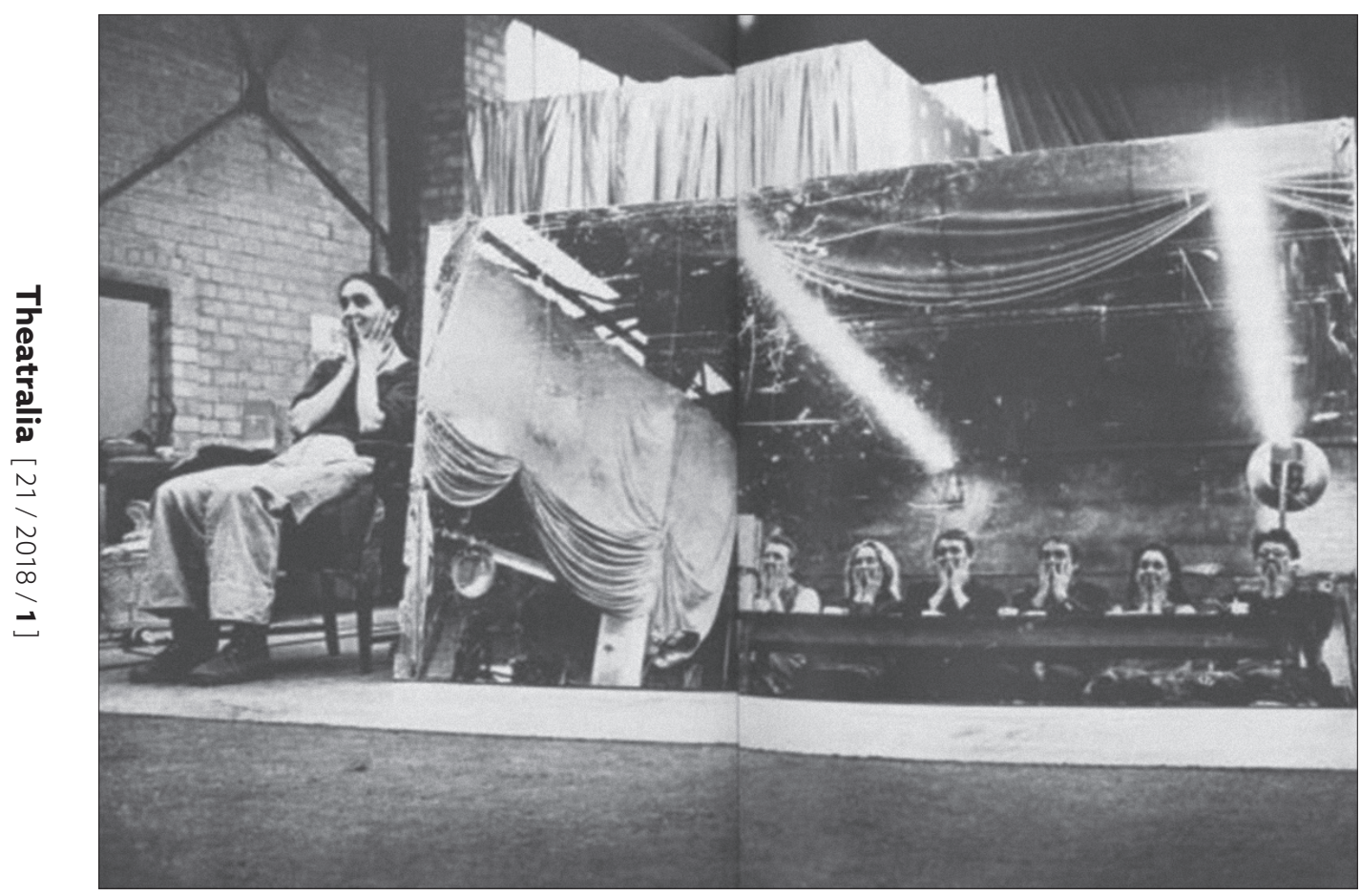

Obr. 5: Tanztheater Wuppertal - zkouška.

blika, tak některých členů souboru, ale Bausch se brzy naučila s ansámblem i publikem zacházet. Pro její vedoucí pozici se spíše než označení umělecká vedoucí či ředitelka hodí slovo principálka, odkazující k rodinným cirkusovým kompaniím. Bausch pěstovala k divadlu i ke každému členu ansámblu až mateřský vztah a vytvářela zde atmosféru rodinného kruhu. Tento způsob jednání byl zvykem v prostředí školy Folgwangschule a Bausch tento model přirozeně přejala od svého učitele Kurta Joosse. Tanečníci ze souboru odcházeli a opakovaně se $\mathrm{k}$ Pině Bausch vraceli i za cenu pobytu v neutěšeném a poněkud bizarním maloměstě Wuppertal, ztraceném mezi ostatními podobně malými městy v oblasti industriálního Porúríí.

Osobní a profesní život Bausch se těžko odděluje. Choreografie a tanec jsou u ní rovnítkem pro její vlastní život a s trochou nadsázky lze říci, že Pinu Bausch tvoří její umělecká práce. Bausch byla známá svým až extrémním smyslem pro zodpovědnost za svou práci, ansámbl i publikum. Bylo více než běžné, že konečnou podobu choreografie měnila ještě během generálky, těsně před představením nebo i po premiéře. Provoz divadla jí většinou neumožnil posunout datum premiéry, takže v př́padě nespokojenosti s konečným tvarem vystoupila před začátkem představení na jeviště a omluvila se publiku za „nehotové“ dílo (ZUTHER 2016). Od tohoto přístupu k souboru a tvorbě se odvijí i její režijně-choreografický styl. 


\section{Stück jako titul a podtitul díla}

Typickým spojujícím rysem většiny produkcí tanztheateru se stalo odmítnutí nadále označovat taneční díla jako inscenace, balet či choreografie. Na počátku ustanovování žánru se většinou objevují názvy produkcí jako Tanzabend (taneční večer), Tanzoper (taneční opera) nebo Operette (opereta). Odklon od výrazů neodlučitelně spojených s konvenční produkcí tance se tak manifestuje již v názvu jednak zařazením mimo oblast klasické taneční inscenace evropského repertoáru, jednak zdůrazněním představení jako události či společného zážitku (Tanzabend) a odkazem na jistou míru hereckého jednání a živou hudbu v taneční choreografii (Tanzoper, Operette). U některých choreografů se objevují ještě specifičtější způsoby pojmenovávání choreografií. Johann Kresnik svá díla například pojmenovává pouhým souslovím Choreographisches Theater (choreografické divadlo), čímž naznačuje inklinaci k divadelnosti svého tance. Pina Bausch byla známá svou až pedantickou zásadovostí v pojmenovávání svých děl. Jednou ze součástí jejího tvưrčího procesu bylo dodržování principu nazývat nové choreografie nejprve jednoduchým neutrálním označením Stück ${ }^{12}$ a pojmenovat je tím správným konkrétním jedinečným názvem až po prvním uvedení, přičemž si ani tehdy Bausch nebyla naprosto jistá, zda volí správně. V praxi to tedy vypadalo tak, že na programech tištěných pro premiérové představení stálo pouhé Stück von Pina Bausch, ve smyslu „dílo nebo choreografie Piny Bausch"13. V programech tištěných pro reprízy je konkrétní název choreografie již uvedený a označení Stück von Pina Bausch se objevuje jako podtitul díla. Poprvé se slovo Stück objevuje v podtitulu choreografie Fürchtet euch nicht (Nižádný strach) z roku 1976. Do té doby označovala své divadelní produkce jako Tanzabend, Tanzoper, Schlagerballet (šlágrbalet), v př́ípadě Mahlerova Adagia pouhé Von Pina Bausch (Od Piny Bausch) nebo i bez předložky Pina Bausch. Dvakrát se slovo Stück objevilo i v samotném názvu choreografie, poprvé v případě stücku 1980 - Ein Stück von Pina Bausch (1980 - Dílo Piny Bausch) a později roku 1993 u díla Das Stück mit dem Schiff (Kus s lodí). V prvním případě tomu tak bylo zřejmě proto, že je stück věnován zemřelému dlouholetému partnerovi Piny Bausch Rolfu Borzikovi, dvornímu scénografovi Tanztheateru Wuppertal, a tudíž toto dílo získalo označením Stück v samotném názvu své výsadní postavení mezi ostatními stücky v dosavadní tvorbě Bausch.

Pina Bausch přistupuje ke svým jednotlivým dílům jako k svébytným existencím, které potřebují svůj čas, aby dozrály, a žijí si svým vlastním životem. Tento postoj odpovídá tezi německého dramatika Heinera Müllera a dalších postmoderních tvůrců o vztahu autora k jeho textu, a sice že „text je chytřejší než jeho autor“ (FUHRMANN 1997: 7). O úctě ke každému jednotlivému dílu a jeho samostatnému bytí svědčí i přání Bausch, aby její choreografie nebyly v žádném případě interpretovány či popisovány ani v programech, ani jiných textech vydávaných produkčním oddělením divadla. ${ }^{14}$

12 V českém překladu znamená substantivum das Stück kus, kousek, díl hovorově i divadelní dílo či divadelní kus.

13 U nás takto postupoval například Petr Lébl, který svá díla označoval nekonkrétně jako inscenace Petra Lébla.

14 Jak se při jednom z našich rozhovorů v zázemí divadla Tanztheater Wuppertal vyjádřila produkční a dlouholetá kolegyně Piny Bausch paní Ursula Popp. 
To znamená, že se v programech mimo datum představení a obsazení nenachází naprosto žádný propagační text či dramaturgické poznámky. Obsahem programů jsou často fotografie z představení, kresby návrhů kostýmů a scény a privátní i profesní fotografie všech členů ansámblu.$^{15} \mathrm{~V}$ př́ípadě operet jsou zde uvedeny úryvky zpívaného textu a někdy jsou zde zveřejněny poznámky ze zkoušek zaznamenané samotnou Bausch označené bud' jako Fragen, Themen, Stichworte (otázky, témata, klíčová slova) nebo Probentagebuch (režijní deník). Tyto dílčí texty odkazují na proces vzniku a původ stücku, nikoliv na konečný výsledek. Na jednu stranu je dílo představeno publiku ve své čistotě, ponechané svému vlastnímu osudu bez předem kladených nároků na výpověd' a způsob, jakým bude promlouvat, na druhou stranu představuje program stücku jeho neoddělitelnou součást, která zůstává zachována v čase jako materiální stopa. Dílo je vytvořené v aktivní jak taneční, tak myšlenkové a dramaturgické spolupráci celého souboru vedeného Bausch a zrcadlí se v něm alespoň kousek každého $\mathrm{z}$ jeho tvůrců. $\mathrm{V}$ poetice tanztheateru jde o koláž v pravém slova smyslu na všech úrovních díla - nejen v metodě práce s hudebními skladbami a pohybem, ale i ve formě choreografie, komponované z jednotlivých menších samostatných obrazů či situací, které spolu zdánlivě nesouvisí. Na principu koláže je vytvořena i vnitřní kostra díla, která je seskládaná z nespočetných podnětů a impulsů všech tanečníků, choreografky, skladeb, potažmo textů a jejich autorů.

\section{Režijní a choreografická metoda osobního příběhu}

\section{Stovky položených otázek}

Při tvorbě adaptace Shakespearova Macbetha Er nimmt sie an der Hand und führt sie in das Schloß, die anderen folgen. Ein Stück von Pina Bausch (Bere ji za ruku a vede do zámku, ostatní následují. Dílo Piny Bausch), který vznikl pro městské činoherní divadlo Bochumer Schauspielhaus začala Bausch společnou práci se souborem stavět především na dialozích. $\mathrm{Z}$ toho později vytvořila vlastní režijní metodu, kterou používala bez výjimky při tvorbě každého dalšího stücku. Adaptace bochumského Macbetha byl projekt, na němž spolupracovali tanečníci Tanztheateru Wuppertal, herci z bochumské činohry a vybraní operní zpěváci ${ }^{16}$. Každý z účinkujících byl nejen různého původu, ale i jiného uměleckého zaměření, což samo o sobě přinášelo spoustu inspirace a podnětů $\mathrm{k}$ experimentům v procesu tvorby. Právě při práci na tomto stücku začala Pina Bausch uplatňovat svou metodu kladení otázek, která sloužila ke sběru materiálu k určitým tematickým celkům. Na počátku každého stücku měla Pina Bausch určitou ideu či téma, ale žádnou jasnou koncepci. Aby ji definovala, kladla tanečníkům otázky týkající se dětství, původu a domu rodičů, zážitků z mládí, citů, pocitování určitých situací, zklamání, zranitelnosti, ale i slavení Vánoc a toho, k jakému použití slouží určité

15 Například program ke stücku Two Cigarettes In The Dark z roku 1985 připomíná spíše rodinné album sestavené z osobních fotografií tanečníků a choreografky a zápisů z režijního deníku.

$16 \mathrm{~V}$ tomto stücku se v jedné z rolí objevila i česká operní pěvkyně Soňa Červená. 
předměty (HOGHE 1986: 84-85). Z odpovědí a pohybových improvizací, které byly závislé na původu tanečníka, jeho kultuře a momentálním duševním rozpoložení, pak vznikala slova, věty, gesta, pózy, pohyby a mikrosituace. Bausch si vedla deníky ze zkoušek, pozorovala, naslouchala, pečlivě si zapisovala všechny momenty, které se jí zdály důležité, a týdny sbírala materiál pro novou choreografii. Pina Bausch popisuje způsob, jakým je potřeba s otázkami nakládat a v čem tkví jejich smysl pro tvorbu takto:

Kladu mnoho otázek, dávám úkoly a týdny sbírám výsledky. Z toho, na čem tanečníci pracovali, se většina nedá použít, [...] hned poznám, co se nehodí. Ve stücku z toho pak vidíte jen zlomky, pět až deset procent. Celkem přesně vím, co hledám [...] na počátku mi však chybí obraz. [...] Jak z tohoto pracovního materiálu vytvořím stück, nedokážu racionálně popsat. Je potřeba obrovský instinkt [...]. Ale jinak je všechno velmi promyšlené. (SCHULZE-REUBER 2005: 73)

Z tohoto př́stupu plyne, že tanečník je pro Pinu Bausch navzdory ohromujícím scénografiím a propracovaným hudebním kolážím ta nejdůležitěǰší složka, ke které se všechny ostatní složky stücku vztahují. Je zároveň rekvizitou i aktérem, který zastupuje všemožné typy všedního člověka (je jeho znakem a odkazuje na něj). ${ }^{17}$ Díky jeho přispění, úplnému psychickému a fyzickému nasazení a jedinečné osobnosti vzniká stück, který je postaven na reálné skutečnosti, nebot na jeho pozadí stojí reální lidé se svými reálnými pocity a vnímáním světa. Tanečníci jsou přítomni ve všech fázích tvorby stücku, od prvních črt po výsledný tvar. Při konkurzu do svého ansámblu se Bausch vedle pohybových kvalit tanečníka zajímala mnohem více o jeho lidskou stránku a schopnosti názorně a kreativně pohybově ztvárnit své vnitřní podněty. Nezajímali ji tanečníci, ale spíše lidé, kteří tančí.

\section{Témata lidské existence a estetika každodennosti}

Pina Bausch pozorovala obyčejné lidi své doby, jejich chování, postoje ke společnosti a zejména jejich vzájemné vztahy. Takové lidi také zobrazovala a jejich témata nechávala rozžít a nahlédnout na scéně. Po uvedení tanečního večera Die sieben Todsünden (Sedm smrtelných hříchů $)^{18} \mathrm{v}$ roce 1976 už nejsou předlohami jejích děl literární díla, dramata či hudební kompozice. Opírá se o každodenní skutečnost a pojednává velká lidská témata jako lásku, strach, touhy, iluze, osamělost, manipulaci, sny, vzpomínky a zapomnění, která se dotýkají bez výjimky každého člověka. To stvrzuje asi nejcitovanější výrok Piny Bausch o její taneční filosofii: „Jde o život; a o to najít pro život jazyk. A pořád dokola jde i o to, co ještě uměním není, ale co se uměním možná stane.“ (WOITAS 2016: 87)

Taneční teoretik a kritik Schulze-Reuber ve své publikaci popisuje Tanztheater Piny Bausch jako zrcadlo lidské duše, přičemž leitmotivem jejích stücků je bez výjimky člověk

17 Nutno dodat, že ansámbl Piny Bausch byl velmi heterogenní i co se národností týče. I na těchto odlišnostech mezi jednotlivými tanečníky Pina Bausch své stücky stavěla.

18 Překlad Ludvíka Kundery. 


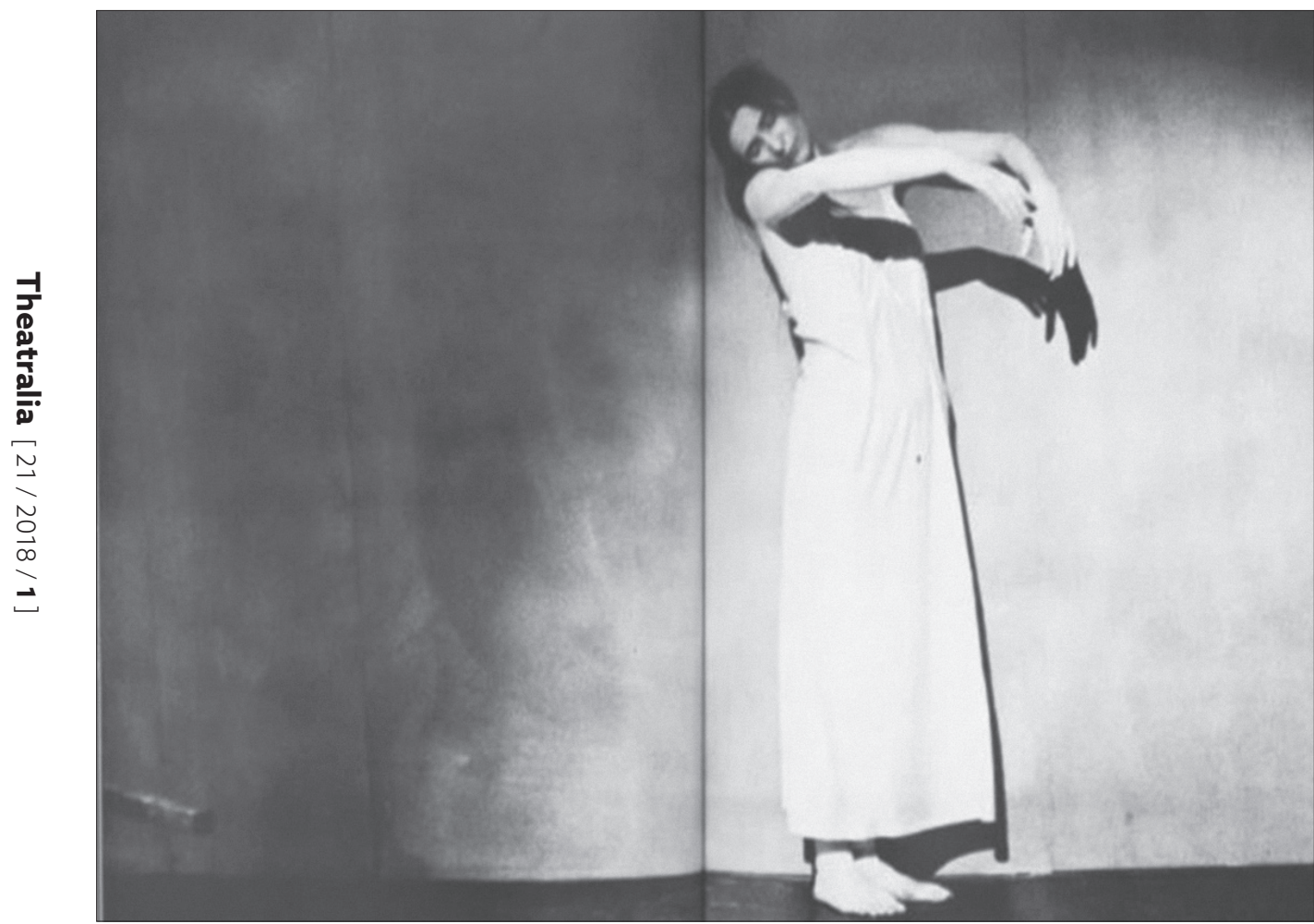

Obr. 6: Pina Bausch tančící ve stücku Café Müller.

se svými všedními problémy. Choreografku nezajímají role lidí ve společnosti, ale to, co je za maskami, které si lidé nasazují (SCHULZE-REUBER 2005). Proto se Bausch zcela oprostila od romantického patosu velkých klasických baletních a hudebních děl a vytvořila si svůj vlastní „patos“, kterým představuje zásadní existenciální lidská témata zdánlivě banálním zpo̊sobem. Komponuje složitou mozaiku vnitřního světa člověka. Zobrazuje lidi a společnost, ale nenabízí žádné konkrétní řešení, jakými by tito lidé a tato společnost měli být. Důvodem toho, proč jsou její díla divácky náročnější, je nelineární dramaturgie bez jednotného příběhu, kterou Bausch pro své choreografie volí. Svou tvorbu nikdy nevysvětlovala a zakazovala uvádět v programech jakoukoliv jejich interpretaci. Klíč k pochopení leží v každém divákovi zvlášt, čímž má být vytržen z pasivity a jeho vlastní každodenní zkušenost má být konfrontována s obrazy díla, které vznikly na základě pozorování každodenního lidského života.

\section{Pohyb: zkušenost a historie těla}

I taneční poetika Bausch vychází ze skutečné každodenní zkušenosti těla, kterou choreografka přejímá do obrazů svých děl jako základ tanečních pohybů. Taneční pohyb nevyrůstá pouze z technického ovládnutí těla a požadavku jeho výhradní taneční 


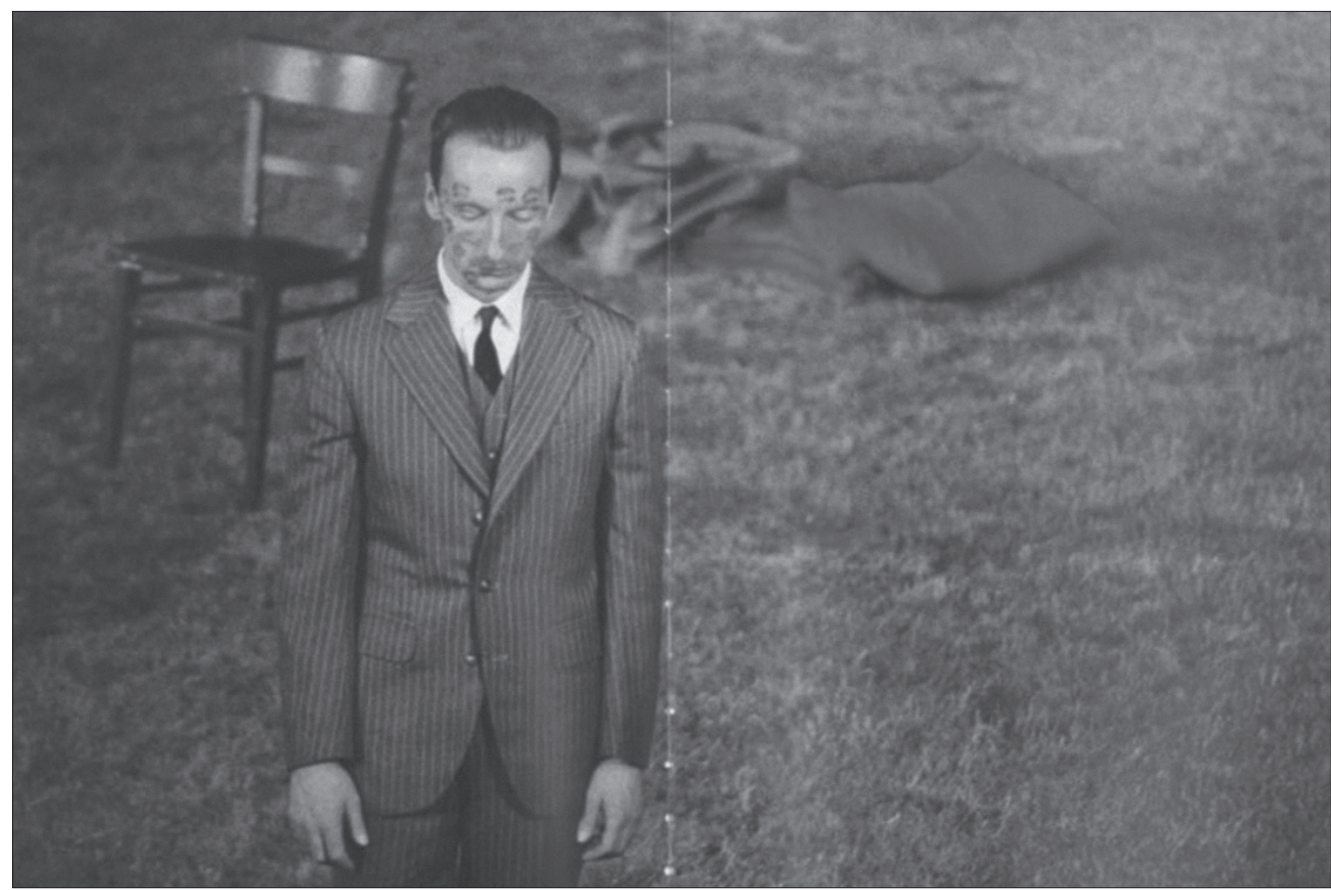

Obr. 7: Tanečník Dominique Mercy ve stücku 1980 - Ein Stück von Pina Bausch.

estetičnosti, nýbrž vzniká i na základě myšlenek a všedních gest. Bausch se do jisté míry vzdala klasické i moderní taneční estetiky, nebot’ se obává její nepravdivosti a neschopnosti působit dostatečně realisticky. Jde jí o podobu realismu, ve které se slévají principy tance a herectví. Důležitý je nejen stylizovaný taneční pohyb, ale i gestikulace, mimika a držení těla, které mají schopnost vyjádřit pocity člověka pokud možno realistickým až naturalistickým způsobem. Tanečníci Piny Bausch nehráli role, nýbrž vystupovali na jevišti sami za sebe. Zároveň zastupovali různorodé lidské prototypy, které často karikovali. Jedinečná osobnost tanečníka představuje „everymana“. Pina Bausch tento princip popisuje slovy: „Nehrajeme jako herci nějakou roli z předložené hry, nýbrž hrajeme sami sebe, my jsme ta hra." (SCHULZE-REUBER 2005: 58) Zpo̊sob, jakým Bausch své ideje divákovi předkládá, je přímý, sarkastický, bez jakéhokoliv přikrašlování a plný komiky, jejímž úkolem je vyvažovat vážnost ve své podstatě pesimisticky vyznívajících stücků. Schulze-Reuber definuje choreografický styl Bausch jako pohyblivý obraz bědování nad nouzí, osaměním individua, násilím a brutalitou. Bausch podle SchulzeReubera ukazuje společnost plnou egoistických zoufalých individuí, která funguje dle zákona „člověk člověku vlkem“19 (SCHULZE-REUBER 2005: 59).

19 Původně Plautův obrat „homo homini lupus“, kterým Thomas Hobbes definuje v teoretickém spisu Leviathan neboli o podstatě, zř́zeni a moci státu církevního a občanského z roku 1651 společnost v přirozeném stavu. 


\section{Tanec: banální a téměř neviditelný}

Otázka tanečního stylu Piny Bausch je diskutována teoretiky a kritiky od konce 70. let. Vytvořila si vlastní pojetí pohybu, ve kterém může tančit každá jednotlivá nejmenší část lidského těla: chodidla, nohy, pozadí, prsty, ruce, paže, hlava. Pohyb sám slouží účelu vypovědět něco určitého i o těch nejvšednějších skutečnostech, a proto je nutné, aby byl motivovaný poučeným a promyšleným záměrem, což jej dělá originálním a ve škále ostatních tanečních stylů jedinečným. V rámci celého stücku však není sám o sobě důležitý, funguje ve vztazích ke všem ostatním složkám. Pina Bausch se odvrací od pohybu svázaného nároky na krásu a hledá inspiraci zejména ve všedním civilním pohybu. Spojení tance a všedního života chápe Pina Bausch takto: „Jak to, že jde jen o samotný tanec? Nerozumím, proč k němu vůbec nepatří svět. V životě se děje nekonečně mnoho věcí a je zajímavé, proč se dějí. I u tance je to skutečně důležité právě důvod, proč tančit." (SCHULZE-REUBER 2005: 85)

Bausch se snaží najít odpověd’ na otázku, co je pravá definice tance: „Jednoduše je to otázka toho, kde tanec začíná, kde ještě ne. (Ve smyslu: kdy se dá u pohybového vyjádření mluvit o tanci a kdy naopak o tanec nejde) Kde je začátek? Čemu se říká tanec? Má to jistě něco společného s vědomím, s vědomím těla, a jak se něco (tělem) formuje. Ale to přece nemusí mít estetickou formu, může mít i docela jinou, a přesto tancem zůstat.“ (SCHULZE-REUBER 2005: 86)

Tančící tělo může být podle Bausch tedy i takové, které nenaplňuje žádné konvenční představy o tanci. Tancem může být gestikulace rukou, stejně jako nehybné tělo. Tanec je i práce s energií a může začínat uvnitř těla docela slyšitelně i viditelně ještě před tím, než si divák povšimne pohybu. Například momenty, kdy tanečník stojí u mikrofonu a dýchá do něj a jiný tanečník, který (z nějakého důvodu emocionálně vzrušený) poslouchá přes mikrofon své bušící srdce, jsou pro Bausch v obou případech tanečním projevem. Veškeré diskuze o tom, zda jde vůbec o tanec, jsou vlastně jen projevem snahy definovat a kategorizovat pojem tanec, což uzavírá některé inspirační kanály a zabraňuje experimentu v tvorbě, tolik typickému pro tvůrce tanztheateru.

\section{Metoda koláže}

Zpo̊sob, jakým Bausch vytvářela své choreografie, se podobá práci s kreativní plochou, na níž postupně vzniká pestrá koláž jednotlivých pohybů, hudby, mikrosituací, jež se spojují v obrazy bez jednotného děje, jakékoliv návaznosti či psychologie postav. ${ }^{20}$ Jednotlivé prvky kombinuje Bausch velmi asociativním způsobem a koláž prozradí svou výpověd’ teprve až se svou poslední částí, která divákovi dotvoří úplnou mozaiku stücku. Na tomto principu se zakládá i jistá iritace a vytrhování diváka z pasivního vnímání.

Formu divadelního díla jako koláže dovedla Bausch k dokonalosti i tím, že opustila tra-

20 V choreografiích nejde o dlouhodobý psychologický vývoj postav. Tanečníci představením emocí vytvářejí spíše nálady a atmosféry, které dotváří taneční koláž. Pokud se ve stücku vyskytne děj, pak je tanečníkem pojednán zvnějšku ve smyslu brechtovského herectví „hrát, že hraji určitou postavu“. 
diční hierarchii hlavních a vedlejších postav. Dalo by se říci, že po uvedení stücku Blaubart pracuje Bausch výhradně s postavami, které mají naprosto rovnoprávné postavení a na žádnou z nich není v rámci celého díla kladen větší důraz než na ostatní. Tanztheater Piny Bausch je často srovnáván s principy epického divadla Bertolta Brechta, nebot stejně jako Brecht požaduje Bausch, aby si bylo publikum vědomé své společenské situace. Zatímco však Brecht nabádá publikum ke změně společenských poměrů, Bausch reálnou skutečnost pouze konstatuje, dává ji s odstupem poznat a v žádném př́ípadě nedává návody, jak tuto situaci řešit. Divák byl v tanztheateru Piny Bausch bez slitování konfrontován $\mathrm{s}$ těmi nejbrutálnějšími obrazy, které však nepodléhaly účelu provokovat. ${ }^{21}$

\section{Zrušení rampy}

Velkou roli hraje v tanztheateru Piny Bausch mluvený a zpívaný projev. Jak popisuje Schulze-Reuber, nejde o celistvé repliky ani dialogy. Jazyk je používán ve své fragmentární podobě, mnohdy jde jen o samostatná slova, útržky vět, výkřriky či jen o nesrozumitelné mumlání. Tyto jazykové prostředky zvýrazňují téma lidského prožitku, a v tanci tak vytváŕí naturalistické rysy. Médiem jazyka si Bausch vypomáhá $\mathrm{k}$ tomu, aby ještě více zahustila sít významů vytvářející obraz skutečného člověka. Jazyk je zde však také prostředkem zcizení divadelní iluze. Mluveným projevem vkládá Bausch do díla většinou komiku nebo sarkasmus, což vytváří odstup od intenzivních emocí představovaných na scéně. Pina Bausch ruší pomyslnou čtvrtou stěnu mimo jiné tak, že tanečníci často oslovují publikum nebo vyzývají jednotlivé diváky k akci. Např́íklad ve stücku Kontakthof (přibl. Dvůr kontaktu / vztahů / doteků) je divák jednou z tanečnic požádán o drobnou minci, kterou performerka hodí do automatu, aby se mohla pohoupat na poutovém houpacím koníkovi na elektřinu. V případě stücku Fürchtet euch nicht zdraví jedna z tanečnic na začátku současně publikum i shromážděný sbor na jevišti. Oznámí tanečníkům, že se společně naučí jednu taneční variaci a převezme roli lektorky na hodině v „taneční škole života“. Pohyb předvede dvakrát sama bez hudby s důsledným didaktickým gestem, posléze společně s tanečníky, a nakonec zatančí všichni dohromady úvodní choreografii stücku bohatou na pitvorné grimasy směřované do publika již za doprovodu agresivní hudební interpretace jednoho ze songů Kurta Weilla. Groteskně působí tanec také díky výrazům ve tváři, vyjadřujícím totální znudění jako například dlouhé pohrdavé zívnutí nebo posílání polibků publiku provázené svraštěním rysů ve tváři.

Ve stücku 1980 jsou tanečníci přímo oslovováni jménem a vyzýváni k odpovědi na otázky, zatímco jsou na jevišti nastoupení v řadě jako na soutěži krásy. Tanečník stejně jako jeho projev stojí na hraně mezi umělým a opravdovým.

21 Jako např́íklad ve stücku Sedm smrtelných nebo stücku Blaubart, které jsou považovány za nejradikálnější Bauschina díla pojednávající ženu ve vztahu k muži jako zboží. 


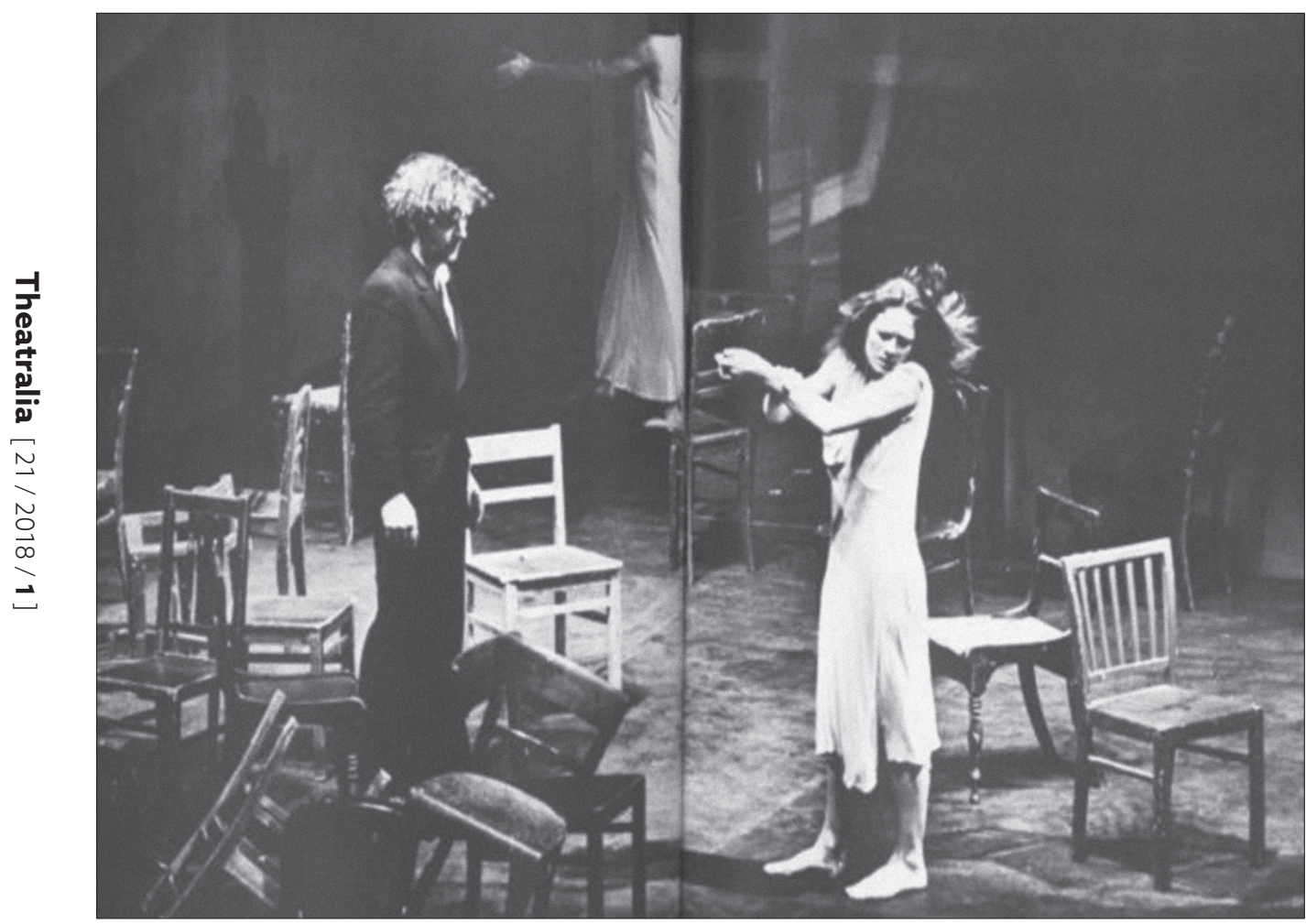

Obr. 8: Rolf Borzik a Malou Airaudo ve stücku Café Müller.

\section{Scénografie}

První scénografie stücků Piny Bausch vytvářel její spolužák z Folkwangschule a posléze i životní partner Rolf Borzik, který však náhle zemřel na rakovinu v lednu 1980. Od tohoto roku až do smrti Piny Bausch zastával funkci dvorního scénografa Tanztheateru Wuppertal Peter Pabst, který nadále rozvíjel výtvarný jazyk Rolfa Borzika. Uspořádání prostoru je v choreografiích velmi důležité, nebot má přímo a záměrně ovlivňovat samotný pohyb tanečníků. Scénografie není pouhou kulisou, ale partnerem v tanci. Jako prŕíklad je možné uvést stück Café Müller z roku 1978, ve kterém jsou po celém jevišti postavené židle a několik stolů. Muž v obleku (původně ztvárněn samotným Rolfem Borzikem) neustále uvolňuje cestu třem tanečnicím, které se pohybují po scéně se zavřenýma očima, aniž by si všímaly překážek. Muž odhazuje židle na stranu vždy o pár momentů dříve, než se s nimi tanečnice stř̌etnou. Dalšími př́iklady scénografí, ve kterých úprava povrchu scény určuje kvalitu pohybu tanečníka, je choreografie Frühlingsopfer (Svěcení jara), ve které je scéna pokryta vrstvou hlíny, nebo stück Blaubart, v níž se tanečníci brodí uschlým listím. Z tvorby Petera Pabsta je neslavněǰší scénografie pro stück Arie, kde je celá scéna zatopena vodou. Tělo tanečníka se chová úplně jinak, pokud má pro pohyb jiné podmínky než ty, které umožňuje podlaha 


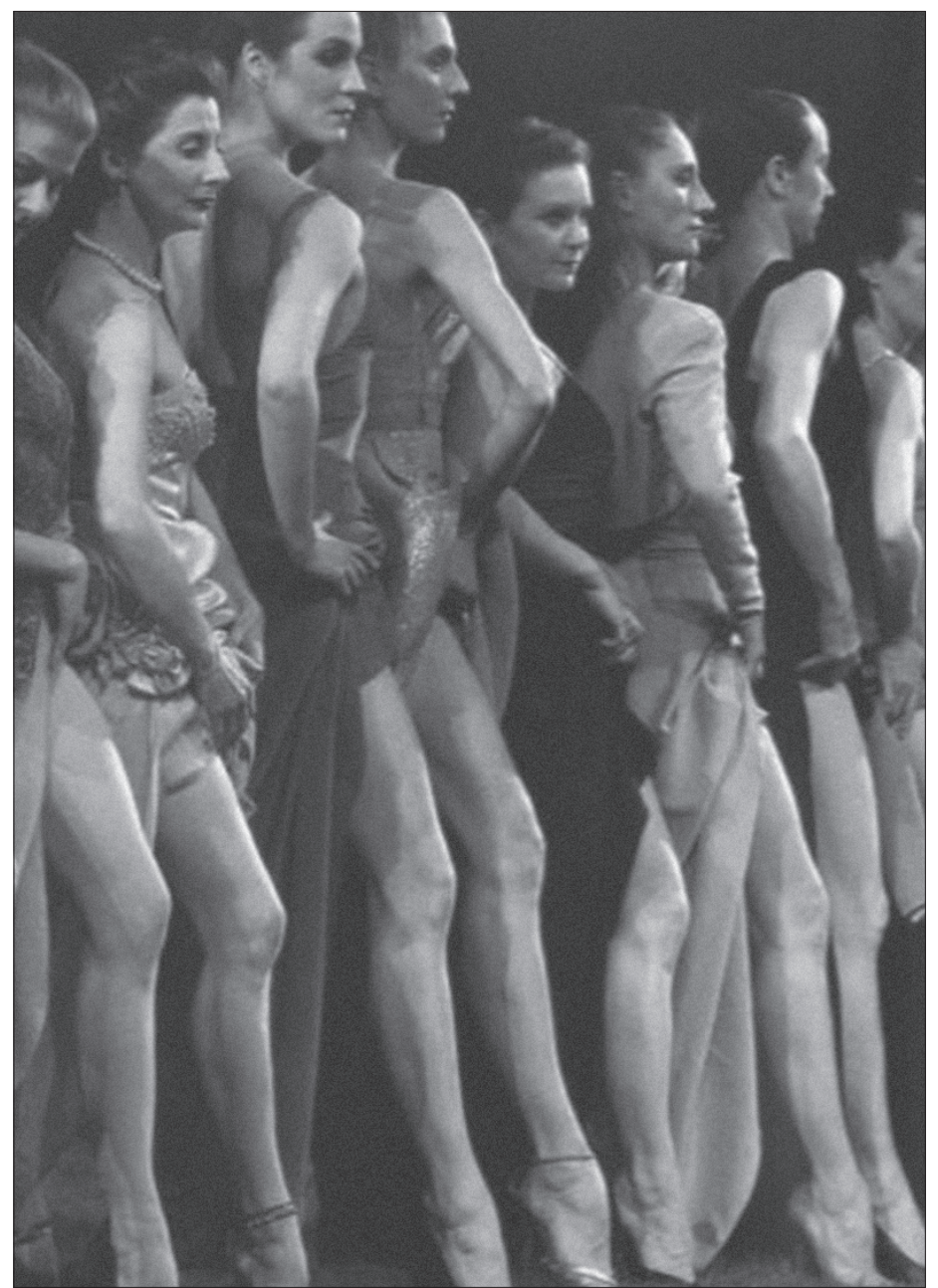

Obr. 9: Scéna soutěže krásy ze stücku 1980 - Ein Stück von Pina Bausch.

baletního sálu. Taková tělesná zkušenost úzce souvisí s opravdovým prožitkem těla a s užitím jiné taneční energie, která přidává do díla novou významotvornou kvalitu. Ve chvíli, kdy musí tělo překonávat překážky jako chlad, hlínu, která se lepí na zpocené tělo, nebo odpor vody, vyjadřuje taneční projev mimo jiné i spontánní úvahy nad existenčními problémy pohybu, což přidává na naturalistickém vyjádření těla. To je podpořeno i zvukem produkovaným jak samotným tělem tanečníka (hlasitý dech), tak manipulací s rekvizitami (např́íklad zmíněné židle).

V souvislosti s rekvizitami a scénografií se dá u Piny Bausch v určité rovině hovořit o poetice zobrazování prázdného či neexistujícího. Absencí lidí či předmětů odkazuje jednak na vzájemné odcizení lidí, chlad, osamění a strach, jednak na touhu po idyle, blízkosti a jistotě. V jejích choreografiích se často objevuje množství prázdných židlí, obleků bez toho, že by je někdo oblékal, holých ramínek na šaty. Hans-Thies Lehmann 


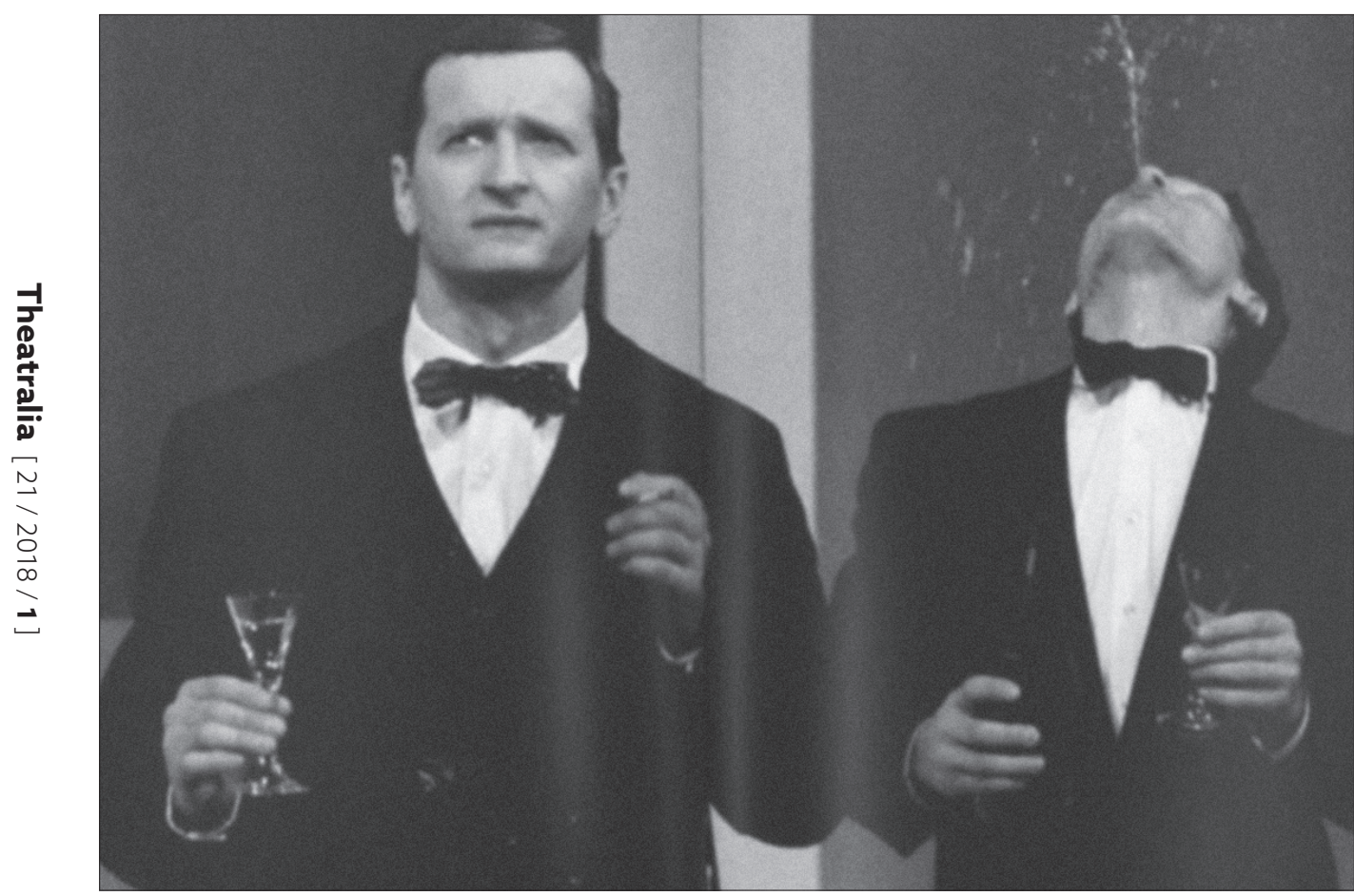

Obr. 10: Two Cigarettes In The Dark. Vlevo tanečník Jan Minařík (Jean Mindo).

popisuje jako jednu z tendencí postdramatického divadla tematický rys prázdnoty, pro který je charakteristická přeplněnost nefunkčními předměty: ,[...] javisko sa mení na hraciu plochu (alebo smetisko) preplnenú predmetmi, spismi a znakmi, chaoticky roztrieštenými asociáciami, ktorých mätúce množstvo vyvoláva pocit zmätku, nespokojnosti, dezorientácie, smútku a horroru vacui - strachu z prázdna." (LEHMANN 2007: 103)

Kostým Pina Bausch nepoužívá jako masku, ale zvolením všedního oděvu zdůrazňuje autentičnost tanečníka jako „průměrného“ reprezentanta člena soudobé společnosti. Tanečník nemá svým stylizovaným oděvem odkazovat na taneční povolání, ale na tančícího člověka, „everymana“, vyjmutého z každodenní reality. Interpret představuje tuto realitu na jevišti a zprostředkovává jako pod lupou její zvětšený obraz zaměřený na detail. Častým kostýmem mužů je pánský oblek, košile, společenské kalhoty a společenské boty, u tanečnic jsou typické běžné letní šaty, dlouhé večerní róby nebo uniformní kostýmky a boty na vysokém podpatku, téměř znemožňující tanec jako takový a nutící jistý unifikovaný pohyb. Kostým má podtrhnout přirozenost (nebo nepřirozenost) lidského těla v jeho každodenním jednání. V choreografiích se také často objevují muži v ženských šatech, ženská nahota a tanečníci tančící naboso, což je naopak prostředek k vytvoření dojmu absurdity či přirozenosti v kontrastu s tělem „svázaným“ v obleku či večerní róbě. 


\section{Závěrem (s ohledem na přesah díla Piny Bausch)}

Jakmile si tanztheater našel cestu k veřejnosti, stal se tento pojem v devadesátých letech velice módním slovem a synonymem pro progresivní baletní soubory téměř ve čtvrtině divadel na území bývalého západního Německa. Nutno však poznamenat, že žánr definovaný tvorbou Piny Bausch, Gerharda Bohnera, Hanse Kresnika, Susanne Linke ad. se značně proměnil a tanztheateru ze sedmdesátých let se současné produkce podobají spíše jen formálně a mísí se s dalšími tanečními přístupy. ${ }^{22}$ Dokonce i tvorba Piny Bausch se v 90. letech značně posunula od původní angažovanosti spíše k uvolněným nekonfliktním poetickým tanečním kolážím, kde již tolik nezáleželo na osobitosti konkrétních tanečníků, kteří jsou v rolích obsazeni, jako tomu bylo dřív. ${ }^{23}$ Dá se říci, že se tanztheater vrátil oklikou k estetice neoklasického baletu, vưči kterému se na konci 60. let vymezoval. Přesto, že se tanztheater jako umělecká forma do určité míry vyčerpal, nic to nemění na tom, že Pina Bausch představuje společně s mnoha dalšími tvůrci 2. poloviny 20. století důležitý mezník v dějinách tanečního a divadelního umění, a to zejména díky uplatňování nového dramaturgického přístupu založeného na principu míšení různorodých prvků v jeden celek. Tím, že si díla vzniklá v tomto období vyžadují svým specifickým charakterem odpovídající způsob analýzy, může jejich zkoumání napomoci k uchopení aktuálních tvưrčích tendencí experimentálních divadelních tvarů.

Jinou perspektivu recepce si vyžadují především takové divadelní projekty, které se dnes svým žánrovým zařazením pohybují na hranici mezi tancem, pohybovým divadlem, experimentální činohrou, výtvarným uměním, audiovisual art, performancí ad., pracující s vědomím rozdílnosti herce (ztělesňujícího postavu) a performera (představujícího do velké míry sebe sama) a vyvíjející osobité tvưrčí přístupy, at̉ už z hlediska prolínajícího se reálného a imaginárního prostoru a času či herecké techniky. Takové divadelní koláže si vyžadují jinou perspektivu recepce, která si nevystačí jen se strukturalistickou analýzou jednotlivých složek inscenace a interpretováním znaků. Dílo tanztheateru se stejně jako současná experimentální divadelní tvorba podobá mnohostrannému vybroušenému diamantu. K celistvému uchopení systému všech konceptů a témat je potřeba uvažovat dílo nikoliv jako jeden imaginární svět, ale jako střet více imaginárních světů, které se navzájem prolínají, komunikují spolu a dohromady tvoří jeden složitý heterogenní celek.

22 Do současné generace tanztheateru, která se inspiruje tvorbou choreografů ze 70. let, patří například Sasha Waltz.

23 Ještě v minulé sezóně, bezmála deset let po smrti Piny Bausch, uvádí Tanztheater Wuppertal úspěšné choreografie ze 70. a 80. let jako například Frühlingsopfer, Café Müller či Nelken v novém obsazení mladých tanečníků. Na jedné straně se takto soubor snaží uchovávat tvorbu Piny Bausch stále živou a přístupnou dalším generacím, na straně druhé je u souboru patrná jistá neschopnost odpoutat se od kultu Bausch a nalézt nové směřování divadla. Více k tomuto tématu se lze dočíst v článku Pina Bausch - již altmodisch? na webu Taneční zóny v rubrice Zahraničí (http://www.tanecnizona.cz/index.php/zahranici/item/573-pina-bausch-jiz-altmodisch). V současné době je novou uměleckou vedoucí Adolphe Binder, která s novou sezónou 2017/2018 obnovila další staré stücky Viktor, Die Sieben Todsünden, Masurca Fogo, Nefés a 1980 Ein Stück von Pina Bausch. Zároveň však budou na jaře 2018 uvedeny dvě premiéry pod názvem Neues Stück I a Neues Stück II, vytvořené ve spolupráci se zahraničními choreografy, což je jistě známkou snahy posunout divadelní soubor k aktuálním tématům a novému tvưrčímu směřování. 


\section{Bibliografie}

FUHRMANN, Helmut. 1997. Warten auf „Geschichte“ Der Dramatiker Heiner Müller. Würzburg: Königshausen und Neumann, 1997.

HOGHE, Raimund. 1986. Pina Bausch: Tanztheatergeschichten. Frankfurt am Main: Suhrkamp, 1986.

HUSCHKA, Sabine. 2002. Moderner Tanz: Konzepte Stile Utopien. Reinbek bei Hamburk: Rowohlt Taschenbuch Verlag, 2002.

CHAMIER, Ille. 1979. Setz dich hin und lächle. Köln: Prometh Verlag, 1979.

JOOSS, Kurt. 1986. Die Sprache des Tanztheaters. Ballett-Journal 34 (1986): 6: 17.

LEHMANN, Hans-Thies. 2007. Postdramatické divadlo [Post-dramatic Theatre]. Bratislava: Divadelný ústav, 2007.

LINSEL, Anne. 2013. Pina Bausch: Bilder eines Lebens. Hamburg: Edel, 2013.

MÜLLER, Hedwig a Norbert SERVOS. 1979. Pina Bausch - Wuppertaler Tanztheater. Köln: BalletBühnen-Verlag, 1979.

MÜLLER, Heiner a Detlef ERLER (edd.). 1994. Pina Bausch. Zürich: Ed. Stemmle, 1994.

SERVOS, Norbert. 1986. In der Fremde. Ballett-Journal 34 (1986): 6: 17.

SCHMIDT, Jochen. 1998. Pina Bausch: Tanzen gegen die Angst. Düsseldorf/München: Econ-undList-Taschenbuch-Verl., 1998.

SCHMIDT, Jochen. 1992. Tanztheater in Deutschland. Frankfurt am Main: Propyläen Verlag, 1992.

SCHULZE-REUBER, Rika. 2005. Das Tanztheater Pina Bausch: Spiegel der Gesellschaft: mit Fotografien von Jochen Viehoff. Frankfurt am Main: R.G. Fischer Verlag, 2005.

WOITAS, Monika a Annette HARTMANN. 2016. Das große Tanz Lexikon: Tanzkulturen Epochen Personen Werke. Regensburg: Laaber-Verlag, 2016.

ZUTHER, Magdalene. 2016. O-Ton Pina Bausch: Interviews und Reden. Wädenswil, Schweiz: Nimbus. Kunst und Bücher, 2016.

\section{Obrazová príloha}

Obr. 1; 4-6; 8-9 CHAMIER, Ille. 1979. Setz dich hin und lächle. Köln: Prometh Verlag, 1979. Foto Ulli Weiss.

Obr. 2 SCHULZE-REUBER, Rika. 2005. Das Tanztheater Pina Bausch: Spiegel der Gesellschaft: mit Fotografien von Jochen Viehoff. Frankfurt am Main: R.G. Fischer Verlag, 2005. Foto Jochen Viehoff.

Obr. 3; 7; 10 MÜLLER, Heiner a Detlef ERLER (edd.). 1994. Pina Bausch. Zürich: Ed. Stemmle, 1994. Foto Detlef Erler. 


\section{Bc. Barbora Kašparová}

Katedra divadelních studií

Filozofická fakulta, Masarykova univerzita, Brno

kaspar.barbora@gmail.com

Bc. Barbora Kašparová (1993) absolvovala bakalářské studium divadelní vědy a germanistiky na Masarykově univerzitě, které ukončila bakalářskou prací na téma Pina Bausch a taneční divadlo všednosti, jejíž stěžejní částí představuje analýza stücku Die sieben Todsünden. V současnosti pokračuje tamtéž $\vee$ magisterském programu ve studiu divadelní vědy a překladatelství němčiny. $\vee$ rámci magisterské diplomové práce se věnuje poetice dramatické tvorby Heinera Müllera. Pravidelně publikuje v časopise Taneční zóna.

Barbora Kašparová (1993) received her BA degree in Theatre History and Theory, and German Language and Literature from Masaryk University (final thesis: Pina Bausch and the Dance Theatre of Everyday, its central part being the analysis of Bausch's stück Die sieben Todsünden). Then she has continued her studies in Theatre and German for MA degree at the same university, concentrating in her Master research on Heiner Müller as dramatist. She writes reviews for Taneční zóna (Dance Zone) journal regularly. 